\title{
High prevalence of hepatitis C in Egyptian patients with chronic liver disease
}

\author{
I A Waked, S M Saleh, M S Moustafa, A A Raouf, D L Thomas, G T Strickland
}

\begin{abstract}
The highest prevalence rates of hepatitis $C$ virus infection in the world have been recently reported among Egyptian blood donors and frequent recipients of transfusions and other blood products. This is the first report, however, demonstrating hepatitis $C$ as the most frequent association with chronic liver disease in Egypt. Of 1023 patients referred to the Liver Institute in Menoufia governorate for evaluation of chronic liver disease, 752 $(73 \cdot 5 \%)$ had antibodies to hepatitis C compared with $168(16 \cdot 4 \%)$ with hepatitis $B$ surface antigen. Hepatitis $C$ antibody was more common in patients with active schistosomiasis and patients without hepatitis B surface antigenaemia. Of 100 patients having liver biopsies, histological findings consistent with chronic viral hepatitis or its complications were found in 89 and antibody to hepatitis $C$ was present in $75(84 \cdot 3 \%)$ of these patients with chronic hepatitis, active cirrhosis or hepatocellular carcinoma. These data pointing to the importance of hepatitis $C$ as a cause of chronic liver disease in Egypt emphasise the necessity of studies delineating its routes of transmission in this country.

Gut 1995; 37: 105-107)
\end{abstract}

Keywords: hepatitis C, hepatitis B, schistosomiasis, epidemiology, chronic liver disease, cirrhosis, chronic hepatitis, hepatocellular carcinoma.

And Biochemistry

A A Raouf

Liver Institute Menoufia University, Shibin El Kom, Egypt

Division of Infectious Diseases, Johns Hopkins University School of Medicine, Baltimore, Maryland, USA

D L Thomas

International Health

Program and

Department of

Epidemiology and

Preventive Medicine,

University of Maryland

School of Medicine,

Baltimore, Maryland,

USA

G T Strickland

Correspondence to: Dr G T Strickland, Department of Epidemiology and Preventive Medicine,

Und Preventive Medicine,

University of Marylanc

Baltimore, MD 21201, USA

Accepted for publication

1 November 1994
Hepatitis $\mathrm{C}$ virus ( $\mathrm{HCV}$ ), the main cause of parenterally acquired non- $A$, non-B hepatitis worldwide, becomes a chronic infection in about $70 \%$ of persons infected. ${ }^{1-3}$ In most chronic cases, $\mathrm{HCV}$ infection progresses to chronic active hepatitis, which in turn may cause cirrhosis and hepatocellular carcinoma. ${ }^{23}$ In Egypt, where hepatitis is an important public health problem, hepatitis B virus (HBV) and schistosomiasis are the most widely recognised causes of liver disease. ${ }^{4}$ Many cases of acute and chronic liver disease in Egypt, however, cannot be related to schistosomiasis or $\mathrm{HBV}$, and antibodies to $\mathrm{HCV}$ (anti-HCV) were detected in two thirds of patients with acute non-A, non-B hepatitis. ${ }^{5}$ In addition, the prevalence of $\mathrm{HCV}(11-22 \%)$ in Egyptian blood donors has recently been reported to be among the world's highest. ${ }^{6-9}$ Despite the high prevalence of HCV in Egypt and its propensity to cause chronic liver disease, the importance of $\mathrm{HCV}$ as a cause of chronic liver disease in Egypt is unknown.
To determine the relative significance of $\mathrm{HCV}$ as a cause of chronic liver disease in Egypt, the prevalence of anti-HCV was determined in a cohort of adult patients with chronic liver disease and compared with the prevalence of hepatitis B surface antigen (HBsAg) and schistosomiasis.

\section{Methods}

From July to December 1992, 1023 adult patients referred to the outpatient clinic of the Liver Institute at Menoufia University were assessed as follows: (1) anti-HCV was detected using a second generation enzyme immunoassay (Ortho Diagnostic Systems, Beerse, Belgium), and a randomly selected subset of 27 samples positive on enzyme immunoassay were also tested using a second generation recombinant immunoblot assay (Ortho Diagnostic Systems); (2) HBsAg was assayed by enzyme immunoassay (Sorin Biomedica, Seluggia, Italy); (3) alkaline and alanine aminotransferase activities were determined by Synchron AS (Beckman Instruments, USA); and (4) abdominal ultrasound was performed by trained clinicians. In addition, rectal snip biopsy specimens were examined microscopically for schistosoma ova in 592 patients who had a history of exposure to schistosome infested water or had clinical findings suggestive of schistosomiasis. Liver biopsy specimens were taken from 100 patients for clinical indications of a suspicious liver mass or persistently increased alanine aminotransferase activity and rated according to the accepted international classification by a pathologist blinded to the serological results.

All laboratory tests and procedures performed upon the patients were believed clinically indicated by the physicians responsible for the patient's care and were not performed for the purpose of this study. Informed consent was obtained before rectal snip and liver biopsies. The study protocol conformed to the ethical guidelines of the 1975 Declaration of Helsinki and was approved by the Liver Institute's human research review committee.

Statistical comparisons were made of the proportion of persons with anti-HCV by sex HBsAg status, and the presence of $S$ mansoni eggs using the Mantel-Haenszel $\chi^{2}$ test (EPI INFO 5.0).

Results

All of the 1023 patients enrolled in this study had clinical, biochemical, or ultrasonographic 
TABLE I Associations of HBs Ag and schistosomal eggs in rectal snip biopsy specimens with anti-HCV in 1023 Egyptian patients with chronic liver disease ${ }^{\star}$

\begin{tabular}{|c|c|c|c|c|c|}
\hline Characteristic & & No & $\% H C V$ & OR $(95 \% C I)$ & p Value \\
\hline \multicolumn{6}{|l|}{ Sex } \\
\hline & $\begin{array}{l}\text { Female } \\
\text { Male }\end{array}$ & $\begin{array}{l}378 \\
645\end{array}$ & $\begin{array}{l}64 \cdot 0 \\
79 \cdot 1\end{array}$ & $\begin{array}{l}1 \cdot 0 \\
2 \cdot 1(1 \cdot 6,2 \cdot 8)\end{array}$ & $<0.001$ \\
\hline HBsAg status & $\begin{array}{l}\text { Positive } \\
\text { Negative }\end{array}$ & $\begin{array}{l}168 \\
855\end{array}$ & $\begin{array}{l}23 \cdot 8 \\
83 \cdot 3\end{array}$ & $\begin{array}{l}1 \cdot 0 \\
16 \cdot 7\end{array}(11 \cdot 1,28)$ & $<0.001$ \\
\hline †S mansoni eggs & $\begin{array}{l}\text { None } \\
\text { Positive - dead } \\
\text { Positive - living }\end{array}$ & $\begin{array}{l}136 \\
128 \\
328\end{array}$ & $\begin{array}{l}68 \cdot 4 \\
62 \cdot 5 \\
82 \cdot 0\end{array}$ & $\begin{array}{l}1 \cdot 0 \\
0 \cdot 8(0 \cdot 5,1 \cdot 3) \\
2 \cdot 1(1 \cdot 3,3 \cdot 4)\end{array}$ & $\begin{array}{l}0.38 \\
0.002\end{array}$ \\
\hline
\end{tabular}

$\star \mathrm{No}=$ number of patients in each category. $\mathrm{OR}=$ odds ratio. $\mathrm{CI}=$ confidence intervals.

$+\chi^{2}$ test for trend (Mantel extension) was also calculated assuming uniform degrees of exposure for none, positive - dead, and positive - living: $p<0 \cdot 001$

evidence of chronic liver disease. The mean age of patients (range) was 42 (16-75) years, and $645(63.0 \%)$ were male. While 767 $(75.0 \%)$ of patients presented to the clinic with symptoms compatible with chronic liver disease, $256(25 \cdot 0 \%)$ were referred because of increased serum aminotransferase activities or asymptomatic liver enlargement.

Of the 1023 patients with chronic liver disease, $752(73.5 \%)$ had anti-HCV and 25 $(92.6 \% ; 95 \%$ confidence intervals $=75.7$ to $99 \cdot 1 \%$ ) of a randomly selected subset of 27 of these were confirmed by supplemental testing. This degree of association between the two tests is in agreement with our experience with other blood samples and with other reports from Egypt. ${ }^{79}$ Anti-HCV was more frequent in men, in patients without $\mathrm{HBsAg}$, and in patients with living $S$ mansoni eggs in rectal snip biopsy specimens in comparison with those without eggs or those with dead eggs (Table 1). HBsAg was detected in 168 $(16.4 \%)$ of 1023 patients.

A histological classification was pursued in 100 patients with clinical indications (Table II). Biopsy specimens from 89 of 100 patients showed pathological changes consistent with chronic viral liver disease: chronic persistent hepatitis, chronic active hepatitis, cirrhosis, or hepatocellular carcinoma. Of these 89 patients, $55(61.8 \%)$ had anti-HCV, $11(12.3 \%)$ had HBsAg, and $20(22.5 \%)$ had both anti-HCV and HBsAg (Table II).

\section{Discussion}

Anti-HCV was present in almost three quarters of outpatients referred for assessment of chronic liver disease and was present in $84 \%$, and the only viral marker in $62 \%$, of those with liver histology consistent with

TABLE II Pathological findings in 100 patients with chronic liver disease according to the presence of anti-HCV or $H B s A g$ in serum samples

\begin{tabular}{lccllr}
\hline & Anti-HCV & $\begin{array}{l}\text { Anti-HCV } \\
\text { and HBsAg }\end{array}$ & HBsAg & $\begin{array}{l}\text { Neither anti- } \\
\text { HCV or HBsAg }\end{array}$ & Total \\
\hline $\begin{array}{l}\text { Chronic persistent } \\
\text { hepatitis }\end{array}$ & $5(71 \cdot 4)$ & $1(14 \cdot 3)$ & 0 & $1(14 \cdot 3)$ & 7 \\
$\begin{array}{l}\text { Chronic active } \\
\text { hepatitis }\end{array}$ & $12(60 \cdot 0)$ & $4(20 \cdot 0)$ & $4(20 \cdot 0)$ & 0 & 20 \\
$\begin{array}{l}\text { Active cirrhosis } \\
\begin{array}{l}\text { Hepatocellular } \\
\text { carcinoma }\end{array}\end{array}$ & $23(59 \cdot 0)$ & $9(23 \cdot 1)$ & $5(12 \cdot 8)$ & $2(5 \cdot 1)$ & 39 \\
$\begin{array}{l}\text { Schistosomal } \\
\text { hepatic fibrosis }\end{array}$ & $15(33 \cdot 3)$ & 0 & $2(8 \cdot 7)$ & 0 & 23 \\
$\begin{array}{l}\text { Other } \\
\text { Totals }\end{array}$ & $2(25 \cdot 0)$ & 0 & 0 & $2(66 \cdot 6)$ & 3 \\
\hline
\end{tabular}

chronic viral hepatitis or its complications. These data show that HCV as an important, if not the primary, cause of chronic liver disease in this region of Egypt. This finding is not unexpected as high rates of anti-HCV were reported in Egyptian blood donors, ${ }^{6-9}$ and in patients with high risk for blood-transmitted infections, ${ }^{8}$ and $\mathrm{HCV}$ is known to cause chronic liver disease histologically identical to that found in our patients. In addition, these data are consistent with reports of the association of anti-HCV with hepatocellular carcinoma. ${ }^{3} 10$

Although these data clearly show the high prevalence of $\mathrm{HCV}$ in Egyptian patients with chronic liver disease, they may underestimate the relative prevalence of $\mathrm{HBV}$ when assessed by HBsAg. Fong et al reported that coinfection of $\mathrm{HBV}$ infected patients with $\mathrm{HCV}$ suppresses HBV replication. ${ }^{11}$ This suppression may cause a decreased expression of HBsAg and an underestimation of $\mathrm{HBV}$ prevalence as reflected by HBsAg and may explain why our patients with HBsAg were less likely to have anti-HCV than those without HBsAg. ${ }^{12}$ The interrelation between $\mathrm{HBV}$ and $\mathrm{HCV}$ is complex; however, another study in Egypt has reported a positive association between the two hepatitis viruses in some blood donors. ${ }^{9}$

In this investigation the prevalence of anti$\mathrm{HCV}$ was greater in patients with active schistosomiasis, as shown by living $S$ mansoni eggs detected by rectal snip biopsy. The increased prevalence of $\mathrm{HCV}$ infection in patients with concomitant schistosomiasis mansoni could be caused by the additive effects of the two hepatic infections leading to an increased likelihood of those with both infections seeking medical care at the Liver Institute. Also, the increased prevalence of $\mathrm{HCV}$ could result from the reuse of needles to give parenteral treatment for schistosomiasis, a common practice before the wide availability of the oral medication, praziquantel, in the past eight or 10 years. ${ }^{13}$ In murine models infection with $S$ mansoni causes increased Th2 cytokine production; a down regulation of interleukin 2, interferon gamma, and virus specific $\mathrm{CD} 8+$ cytotoxic $\mathrm{T}$ cells; and a decrease in clearance of a concomitant viral infection. ${ }^{1415}$ In humans similar immunological suppression from chronic schistosomiasis may lead to less control of viral replication and higher circulating titres of $\mathrm{HBV}$ or $\mathrm{HCV}$, as previously suggested by Ghaffar et $a l .{ }^{4}$ These changes may increase the likelihood of chronic infection and the efficiency of $\mathrm{HCV}$ transmission. Immune suppression from human immunodeficiency virus has been shown to increase both perinatal and sexual transmission of HCV.1617 Schistosomiasis related immune suppression may similarly enhance transmission and contribute to the very high prevalence of $\mathrm{HCV}$ in Egypt.

Given the apparent magnitude of $\mathrm{HCV}$ induced chronic liver disease in Egypt and the morbidity associated with this condition, future studies of the routes of $\mathrm{HCV}$ transmission and the risk factors that enhance $\mathrm{HCV}$ acquisition are urgently needed. 
1 Alter HJ, Purcell RH, Shih JW, Melpolder JC, Houghton $\mathrm{M}, \mathrm{Choo} \mathrm{Q}-\mathrm{L}$, et al. Detection of antibody to hepatitis C virus in prospectively followed transfusion recipients with acute and chronic non-A, non-B, hepatitis. $N$ Engl $\mathcal{F}$ Med 1989; 321: 1494-500.

2 Alter MJ, Margolis HS, Krawczynski K, Judson FN, Mares A, Alexander WJ, et al. The natural history of community A, Alexander WJ, et al. The natural history of community
acquired hepatitis $\mathrm{C}$ in the United States. $N$ Engl $\mathcal{f}$ Med acquired hepatitis $C$ in

3 Yano $M$, Yatsuhashi $H$, Inoue $O$, Inokuchi $K$, Koga $M$. Epidemiology and long term prognosis of hepatitis $\mathrm{C}$ virus infection in Japan. Gut 1993; 34 (suppl 2): S13-6.

4 Ghaffar YA, Fattah SA, Kamel M, Badr RM, Mahomed FF, Strickland GT. The impact of endemic schistosomiasis on acute viral hepatitis. Am $\mathcal{F}$ Trop Med Hyg 1991; 45: 743-50.

5 El-Zayadi A, Selim O, Rafik M, El-Haddad S. Prevalence of hepatitis $\mathrm{C}$ virus among non-A, non-B-related liver disease in Egypt. $f$ Hepatol 1992; 14: 416-7.

6 Saeed AA, Al-Admawi AM, Al-Rasheed A, Fairclough D, Bacchus R, Ring C, et al. Hepatitis C virus infection in Egyptian volunteer blood donors in Riyadh. Lancet 1991; 338: 459-60.

7 Kamel MA, Ghaffar YA, Wasef MA, Wright M, Clark LC, Miller FD. High HCV prevalence in Egyptian blood donors. Lancet 1992; 340: 427.

8 Hibbs RG, Corwin AL, Hassan NF, Kamel M, Darwish M, Edelman R. The epidemiology of antibody to hepatitis C in Egypt. F Infect Dis 1993; 168: 789-90.

9 Darwish MA, Raouf TA, Rushdy P, Constantine NT, Rao MR, Edelman R. Risk factors associated with a high seroprevalence of hepatitis $\mathrm{C}$ virus infection in Egyptian blood donors. Am f Trop Med Hyg 1993; 49: 440-7.
10 Simonetti RG, Camma C, Fiorello F, Cottone M, Papicetta M, Marino L, et al. Hepatitis C virus infection as a risk factor for hepatocellular carcinoma in patients with cirrhosis. Ann Intern Med 1992; 116: 97-102.

11 Fong T-L, Di Bisceglie AM, Waggoner JG, Banks SM, Hoofnagle JH. The significance of antibody to hepatitis C virus in patients with chronic hepatitis. B. Hepatology virus in patients

12 Sheen I-S, Liaw Y-F, Chu C-M, Pao C-C. Role of hepatitis $C$ virus infection in spontaneous hepatitis $B$ surface antigen clearance during chronic hepatitis $B$ virus infection. f Infect Dis 1992; 165: 831-4.

13 Madwar MA, El Tahawy M, Strickland GT. The relationship between uncomplicated schistosomiasis and hepatitis B infection. Trans $R$ Soc Trop Med Hyg 1989; 83: 233-6.

14 Actor JK, Shirai M, Kullberg MC, Buller RML, Sher A, Berzofsky JA. Helminth infection results in decreased virus-specific $\mathrm{CD} 8+$ cytotoxic $\mathrm{T}$-cell and $\mathrm{Th} 1$ cytokine responses as well as delayed virus clearance. Proc Natl Acad Sci USA 1993; 90: 948-52.

15 Sher A, Fiorentino D, Caspare P, Pearce E, Mosmann T. Production of IL-10 by CD $4+$ T lymphocytes correlates Production of IL-10 by CD4+ T lymphocytes correlates
with down-regulation of Th1 cytokine synthesis in with down-regulation of Th1 cytokine synthe
helminth infection. F Immunol 1991; 147: 2713-6.

16 Novati R, Thiers V, Monforte AD, Maisonneuve P, Principi $\mathrm{N}$, Conti $\mathrm{M}$, et al. Mother-to-child transmission of hepatitis $C$ virus detected by nested polymerase chain reaction. f Infect Dis 1992; 165: 720-3.

17 Eyster ME, Alter HJ, Aledort LM, Quan S, Hatzakis A, Goedert JJ. Heterosexual co-transmission of hepatitis C virus (HCV) and human immunodeficiency virus (HIV). Ann Intern Med 1991; 115: 764-8. 